\title{
Bioerosion: a collection of workshop papers
}

\author{
RICHARD G. BROMLEY \\ https://doi.org/10.37570/bgsd-1998-45-13
}

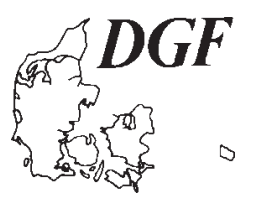

The First International Bioerosion Workshop was held, under the auspices of Geological Institute of the University of Copenhagen, Denmark, at Limensgade Windmill, Aakirkeby, Bornholm in September 1996. The workshop was convened by Richard Bromley and Ulla Asgaard with the object of gathering disparate bioerosionists together under one roof for a week and testing their interest in common ground (Asgaard \& Bromley 1997; Bertling 1997). The success of the venture was indicated by the willing response of participants to write papers for collected publication. It was initially the intention to publish these papers as a special issue of Historical Biology. Unfortunately, the journal ran into trouble when it changed editor and copy-setters simultaneously. As late as second proof stage, following prolonged copy-setting problems, Historical Biology decided not to publish the shorter papers in the collection.

The major papers, however, were retained and have now been published. These are: Jacobsen (1998), Freiwald (1998), Freiwald \& Wilson (1998), Boerboom et al. (1998), Walker et al. (1998) and Hallock et al. (1998). The delay in publishing the remaining thirteen shorter papers is much regretted. They have been collected together here after updating by the authors. Together with the Historical Biology papers, they illustrate a wide variety of bioerosional research. Included are papers on microbial bioerosion, coral reef bioerosion budgets, the work of boring bivalves (in rock and wood), sponges, unidentified organisms, carnivory of foraminifera, hardsubstrate trace fossils, brachiopods as bioerosion substrates and terrestrial bioerosion as well as the use of coastal bioerosion and littoral notches as indicators of palaeo-shorelines.

The second International Bioerosion Workshop was convened by Debra Krumm at Fort Pierce, Florida in March 1998 and the third is planned for Barcelona in 2000.

R. G. Bromley, Geologisk Institut, University of Copenhagen, Øster Voldgade 10, DK-1350 Copenhagen K, Denmark. 1 December, 1998.

\section{References}

Asgaard, U. \& Bromley, R. G. 1997. Bioerosion: den første internationale workshop holdt på Bornholm. Geologisk Tidsskrift 1997 (2): 13.

Bertling, M. 1997: 'Endolithos' - First International Workshop on Bioerosion, 2nd-7th September, 1996. Lethaia $29,310$.

Boerboom, C. M., Smith, J. E. \& Risk, M. J. 1998: Bioerosion and micritization in the deep sea coral Desmophylum cristagalli. Historical Biology 13, 53-60.

Freiwald, A. 1998: Microbial maceration and carbonate dissolution on cold-temperate shelves. Historical Biology $13,27-35$.

Freiwald, A. \& Wilson, J. B. 1998: Taphonomy of modern deep, cold-temperate water coral reefs. Historical Biology $13,37-52$.

Hallock, P., Talge, H. K., Williams, D. E. \& Harney, J. N. 1998: Borings in Amphistegin (Foraminiferida): evidence of predation by Floresina amphiphaga (Foraminiferida). Historical Biology 13, 73-76.

Jacobsen, Aa. R. 1998: Feeding behaviour of carnivorous dinosaurs as determined by tooth marks on dinosaur bones. Historical Biology 13, 17-26.

Walker, S. E., Parsons-Hubbard, K., Powell, E. N. \& Brett, C. E. 1998: Bioerosion or bioaccumulation? Shelf-slope trends for epibionts and endobionts on experimentally deployed gastropod shells. Historical Biology 13, 6172 . 